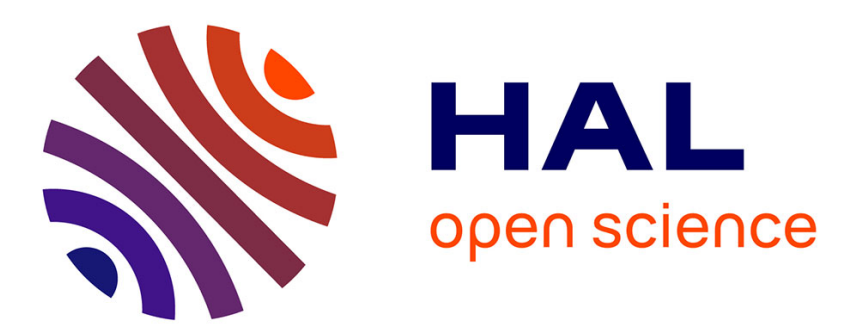

\title{
Electronic and geometrical manipulation of the excited state of bis-terdentate homo- and heteroleptic ruthenium complexes
}

\author{
Joydev Dinda, Sébastien Liatard, Jérôme Chauvin, Damien Jouvenot, \\ Frédérique Loiseau
}

\section{To cite this version:}

Joydev Dinda, Sébastien Liatard, Jérôme Chauvin, Damien Jouvenot, Frédérique Loiseau. Electronic and geometrical manipulation of the excited state of bis-terdentate homo- and heteroleptic ruthenium complexes. Dalton Transactions, 2011, 40, pp.3683. hal-00702892

\section{HAL Id: hal-00702892 \\ https://hal.science/hal-00702892}

Submitted on 31 May 2012

HAL is a multi-disciplinary open access archive for the deposit and dissemination of scientific research documents, whether they are published or not. The documents may come from teaching and research institutions in France or abroad, or from public or private research centers.
L'archive ouverte pluridisciplinaire HAL, est destinée au dépôt et à la diffusion de documents scientifiques de niveau recherche, publiés ou non, émanant des établissements d'enseignement et de recherche français ou étrangers, des laboratoires publics ou privés. 


\title{
Transactions
}

Cite this: Dalton Trans., 2011, 40, 3683

wWW.rsc.org/dalton

PAPER

\section{Electronic and geometrical manipulation of the excited state of bis-terdentate homo- and heteroleptic ruthenium complexes $\dagger$}

\author{
Joydev Dinda, \$ Sébastien Liatard, Jérôme Chauvin, Damien Jouvenot* and Frédérique Loiseau* \\ Received 9th September 2010, Accepted 20th January 2011 \\ DOI: 10.1039/c0dt01197e
}

\begin{abstract}
This work describes the synthesis and characterization of two new bis-terdentate $\mathrm{Ru}$ (II) complexes. Compound $\mathbf{1}$ is a homoleptic complex containing two CNC $N$-heterocyclic carbene (NHC) based ligands, whereas compound $\mathbf{2}$ bears one $\mathrm{CNC}$ ligand and an ancillary terpyridine ligand. The redox and photophysical properties of both compounds have been investigated and their X-ray crystal structures determined. Complex 1 displays a close-to-perfect octahedral coordination geometry and is not luminescent at room temperature while complex $\mathbf{2}$ features room temperature and $77 \mathrm{~K}$ luminescence despite its partially distorted geometry. The presence of the NHC moieties brings a significant amount of electronic density to the metal centre therefore lowering its oxidation potential with respect to that of analogous polypyridyl complexes.
\end{abstract}

\section{Introduction}

Despite the thorough investigations on ruthenium(II) polypyridyl complexes, these are still the object of intensive research. The archetype complex and certainly one of the most widely studied, $\left[\mathrm{Ru}(\mathrm{bpy})_{3}\right]^{2+}$ (bpy $=2,2^{\prime}$-bipyridine), features an energetic triplet metal to ligand charge transfer $\left({ }^{3} \mathrm{MLCT}\right)$ excited state with a relatively long lifetime at room temperature $(\sim 1 \mu \mathrm{s})$ thus making it an ideal photosensitizer. ${ }^{1}$ However, the tris-chelate coordination mode becomes an issue if such a complex is included in vectorial charge separation devices. ${ }^{2 c}$ Not only does this geometry lead to chirality but it also yields to cis and trans isomers when substituted by two functional groups. For the sake of linearity and a maximum structural separation between an electron donor and an acceptor, only the latter isomer should be obtained. Bis-terdentate complexes prevent any isomerism, and central functionalization of the ligands ensures a linear assembly of the components. Unfortunately the bis-terdentate analog of $\left[\mathrm{Ru}(\mathrm{bpy})_{3}\right]^{2+}$, namely $\left[\mathrm{Ru}(\text { tpy })_{2}\right]^{2+}$ (tpy $=2,2^{\prime}: 6^{\prime}, 2^{\prime \prime}$-terpyridine), is practically non luminescent at room temperature, because of possible thermal population, from the ${ }^{3}$ MLCT state, of a close-lying non emitting metal centred (MC) excited state. Many groups have contributed to the improvement of the photophysical properties of such complexes, ${ }^{2}$ in particular either by lowering

Département de Chimie Moléculaire, UMR CNRS 5250, ICMG - FR 2607, Université Joseph Fourier, BP 53, 38041, Grenoble Cedex 9, France. E-mail:

fr, frederique.loiseau@ujf-grenoble.fr damien.jouvenot@ujf-grenoble.

$\uparrow$ CCDC reference numbers 808239 and 808240 . For crystallographic data in CIF or other electronic format see DOI: 10.1039/c0dt01197e

$\$$ Present address: School of Applied Science, "Applied Synthetic Chemical Research Lab.”, Haldia Institute of Technology, Haldia-721657, Purba Medinipur, West Bengal, India. the energy of the triplet MLCT excited state, or by increasing the MC state energy, the common goal being to place the two states as far as possible from one another. In recent years, very elegant examples have been published ${ }^{3}$ where it becomes clear that the coordination geometry around the ruthenium atom is essential. In order to reach a strong ligand field thus preventing dissociative d-d transitions, the coordination polyhedron should be as close as possible to a perfect octahedron. This control can be achieved by using a terdentate ligand forming six-membered metallacycles. In this context, Hammarström et al. described a homoleptic complex $\left(\left[\mathrm{Ru}(\mathrm{dqp})_{2}\right]^{2+} ;\right.$ dqp $=2$,6-diquinolin-8ylpyridine) with exceptional photophysical features $(\Phi=0.02$; $\tau=3 \mu$ s in $\mathrm{MeOH}-\mathrm{EtOH}$ at room temperature). ${ }^{\text {a }}$ This unique ligand provides $\mathrm{N}-\mathrm{Ru}-\mathrm{N}$ bite angles close to $90^{\circ}$ inducing a strong ligand field therefore a high $\mathrm{MC}$ energy in addition to an extended aromatic surface that lowers the energy levels of the $\pi^{*}$ orbitals of the ligand and hence the energy of the MLCT state. These combined characteristics provide a large separation between the energy levels of the ${ }^{3}$ MLCT and the ${ }^{3} \mathrm{MC}$ states. Also by expanding the coordination cage Ruben et al. ${ }^{3 \mathrm{~b}}$ obtained spectacular results. The ligand consists of a central pyridine substituted with two 2-carbonylpyridines. The homoleptic Ru(II) complex of this expanded ligand displays enhanced photophysical properties $(\Phi=0.3 ; \tau=3.30 \mu$ s at room temperature in acetonitrile). With the growing interest in $N$-heterocyclic carbene ligands as a versatile alternative to pyridines, we used a previously reported ligand, 1,1'-[2,6-pyridinediylbis(methylene)]bis[3methylimidazolium]dibromide, ${ }^{4 a}$ that would meet the structural requirements mentioned above. Both a homoleptic and a heteroleptic complex have been synthesized. For the heteroleptic one, well-known terpyridine was used as an ancillary ligand. 


\section{Results and discussion}

The 1,1'-[2,6-pyridinediylbis(methylene)]bis[3-methylimidazolium]dibromide ligand (L) provides adequate connectivity to yield to the required six-membered metallacycles. Ligand L was prepared from 2,6-bis(bromomethyl)pyridine and 1methylimidazole according to the literature. ${ }^{4 a}$ The homoleptic complex $\left[\mathrm{Ru}^{\mathrm{II}} \mathbf{L}_{2}\right]^{2+}$ (1) (see Fig. 1) was formed by reacting ligand $\mathbf{L}$ with $\mathrm{RuCl}_{3}$ in ethylene glycol at $140{ }^{\circ} \mathrm{C}$ in the presence of sodium acetate as a base. Column chromatography followed by anion exchange yielded the hexafluorophosphate salt of complex 1 as a bright yellow solid. Slow diffusion of diethylether into a solution of $\mathbf{1}$ in acetonitrile afforded single crystals suitable for X-ray diffraction (Fig. 2). The unit cell includes two formula units of complex 1. The helical folding of ligand $\mathbf{L}$ around the ruthenium atom gives rise to stereoisomerism. Both $P$ and $M$ helices are found in the unit cell.
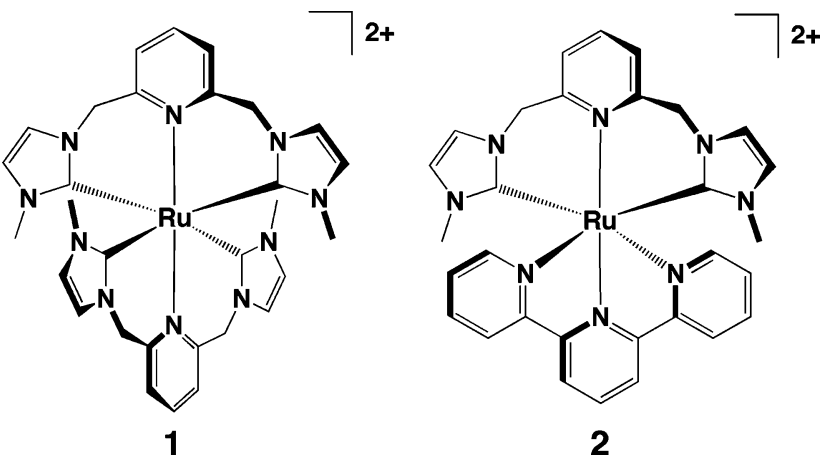

Fig. 1 Complexes 1 and 2. Counteranions are omitted for clarity.

The ${ }^{1} \mathrm{H}$ NMR spectrum of complex 1 features four signals in the aromatic region. A triplet (7.91 ppm) and a doublet (7.65 ppm) are assigned to the pyridine ring and two sharp doublets (7.41 and $7.04 \mathrm{ppm}$ ) to the imidazolidene rings. As seen in previous reports on similar complexes, ${ }^{4}$ the bridging methylene protons appear as a set of two doublets (5.48 and $\left.4.43 \mathrm{ppm} ;{ }^{2} J=15.4 \mathrm{~Hz}\right)$. This behavior is attributed to the twisted conformation of the ligand
Table 1 Selected angles and bond lengths for complexes 1, 2 and $\left[\mathrm{Ru}(\mathrm{tpy})_{2}\right]\left(\mathrm{PF}_{6}\right)_{2}{ }^{5}$

\begin{tabular}{llll}
\hline & $\mathbf{1}^{a}$ & $\mathbf{2}^{b}$ & {$\left[\mathrm{Ru}(\text { tpy })_{2}\right]\left(\mathrm{PF}_{6}\right)_{2}$} \\
\hline Angle (') & & & \\
$\mathrm{C} 1-\mathrm{Ru}-\mathrm{N} 1$ & $86.8(3)$ & $86.5(2)$ & - \\
$\mathrm{N} 1-\mathrm{Ru}-\mathrm{C} 2$ & $86.7(1)$ & $87.6(2)$ & - \\
$\mathrm{C} 1-\mathrm{Ru}-\mathrm{C} 2$ & $172.3(1)$ & $173.6(2)$ & - \\
$\mathrm{N} 2-\mathrm{Ru}-\mathrm{N} 3$ & - & $79.2(2)$ & $79.5(3)$ \\
$\mathrm{N} 2-\mathrm{Ru}-\mathrm{N} 4$ & - & $79.3(2)$ & $79.0(3)$ \\
$\mathrm{N} 3-\mathrm{Ru}-\mathrm{N} 4$ & - & $158.6(2)$ & $158.4(3)$ \\
Bond length (̊) & & & \\
$\mathrm{Ru}-\mathrm{C} 1$ & $2.059(4)$ & $2.097(5)$ & - \\
$\mathrm{Ru}-\mathrm{N} 1$ & $2.120(3)$ & $2.183(4)$ & - \\
$\mathrm{Ru}-\mathrm{C} 2$ & $2.073(4)$ & $2.088(5)$ & - \\
$\mathrm{Ru}-\mathrm{N} 2$ & - & $1.946(4)$ & $1.981(7)$ \\
$\mathrm{Ru}-\mathrm{N} 3$ & - & $2.089(4)$ & $2.076(6)$ \\
$\mathrm{Ru}-\mathrm{N} 4$ & - & $2.070(4)$ & $2.067(7)$ \\
${ }^{a} \mathrm{Counterion}: \mathrm{PF}_{6}{ }^{-} \cdot{ }^{b}$ Counterion: $\mathrm{Br}^{-}$. & \\
\hline
\end{tabular}

once coordinated (Fig. 2). The slow fluxionality on the NMR time scale makes the two protons inequivalent and diastereotopic.

The heteroleptic complex $\left[\mathrm{Ru}^{\mathrm{II}} \mathbf{L}(\mathrm{tpy})\right]^{2+}(\mathbf{2})$ bearing a terpyridine ligand and ligand $\mathbf{L}$ was prepared by reacting $\left[\mathrm{Ru}(\mathrm{tpy}) \mathrm{Cl}_{3}\right]$ with one equivalent of $\mathbf{L}$ in ethylene glycol at $140{ }^{\circ} \mathrm{C}$, using sodium acetate as a base. Purification by column chromatography followed by an anion exchange using $\mathrm{KPF}_{6}$ provided the desired compound as a red powder in moderate yield. Suitable single crystals of complex 2 with bromide counterions were obtained by slow diffusion of an acetonitrile solution of the hexafluorophosphate salt of $\mathbf{2}$ into a saturated solution of $\mathrm{N}\left(\mathrm{C}_{2} \mathrm{H}_{5}\right)_{4} \mathrm{Br}$ in acetonitrile. The in situ anion metathesis yielded the poorly soluble dibromide salt, which crystallized out (Fig. 2). Selected angles and bond lengths for complexes $\mathbf{1}$ and $\mathbf{2}$ as well as for $\left[\mathrm{Ru}^{\mathrm{II}}(\mathrm{tpy})_{2}\right]\left(\mathrm{PF}_{6}\right)_{2}$ are listed in Table 1. It appears clear that the geometrical features of complex 2 are a simple combination of those of its homoleptic analogues with minor deviation. Complex 1 displays a geometry close to a perfect octahedron whereas the well-known $\left[\mathrm{Ru}^{\mathrm{II}}(\mathrm{tpy})_{2}\right]\left(\mathrm{PF}_{6}\right)_{2}$ complex is highly distorted. Logically, complex $\mathbf{2}$ inherits both properties and
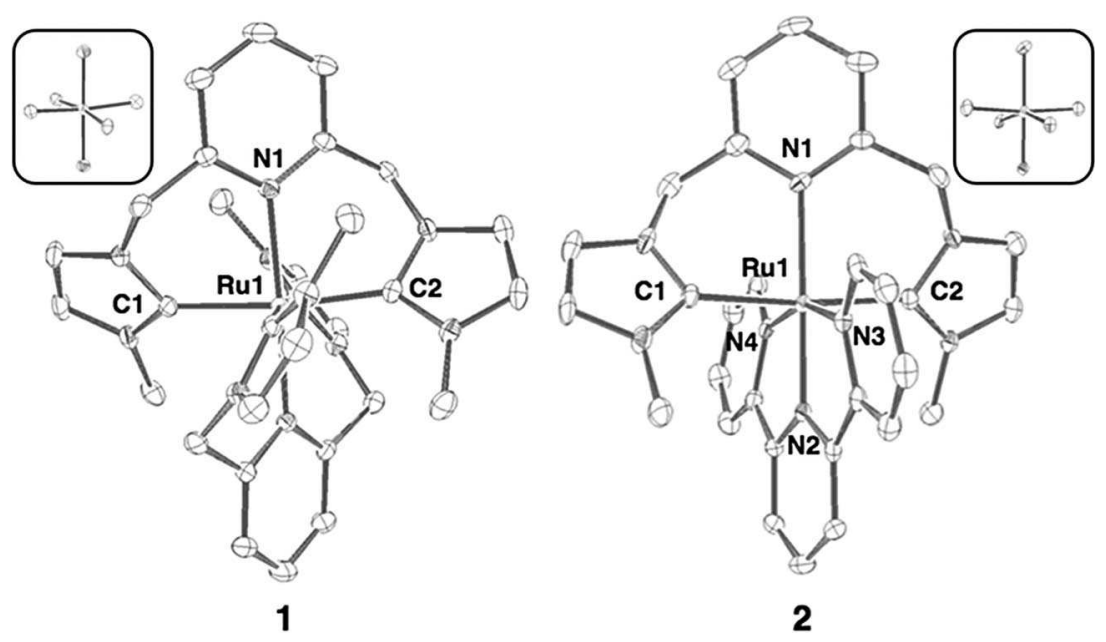

Fig. 2 View of the crystal structures of complexes $\mathbf{1}$ and 2. Solvent molecules, $\mathrm{H}$ atoms and anions are omitted for clarity. For complex $\mathbf{1}$, only one of the two independent molecules present in the asymmetric unit is shown. Ellipsoids are scaled to enclose 30\% of the electronic density. Inserts show the coordination geometry around the ruthenium atom for each compound. The crystallographic data of complexes $\mathbf{1}$ and $\mathbf{2}$ are gathered in Table 2. 
Table 2 Crystallographic data for complexes $\mathbf{1}$ and $\mathbf{2}$

\begin{tabular}{lll}
\hline Compound reference & $\mathbf{1} \cdot\left(\mathrm{PF}_{6}\right)_{2}$ & $\mathbf{2} \cdot \mathrm{Br}_{2}$ \\
\hline Chemical formula & $\mathrm{C}_{30} \mathrm{H}_{34} \mathrm{~F}_{12} \mathrm{~N}_{10} \mathrm{P}_{2} \mathrm{Ru}$ & $\mathrm{C}_{32} \mathrm{H}_{31} \mathrm{Br}_{2} \mathrm{~N}_{9} \mathrm{Ru}$ \\
Formula mass & 925.66 & 802.54 \\
Crystal system & Monoclinic & $\mathrm{Monoclinic}$ \\
Space group & $P 2 / c$ & $C 2 / c$ \\
$\boldsymbol{a} / \AA$ & $21.715(1)$ & $37.10(1)$ \\
$\boldsymbol{b} / \AA$ & $9.014(3)$ & $11.357(6)$ \\
$\boldsymbol{c} / \AA$ & $20.493(2)$ & $16.695(2)$ \\
$\boldsymbol{a}\left(^{\circ}\right)$ & 90 & 90 \\
$\boldsymbol{\beta}\left(^{\circ}\right)$ & $116.975(1)$ & $116.36(2)$ \\
$\boldsymbol{\gamma}\left(^{\circ}\right)$ & 90 & 90 \\
Unit cell volume/ $\AA^{3}$ & $3575(1)$ & $6302(4)$ \\
$\boldsymbol{T} / \mathbf{K}$ & 200.0 & 200.0 \\
No. of formula units per unit cell, $\boldsymbol{Z}$ & 4 & 8 \\
No. of reflections measured & 51323 & 25426 \\
No. of independent reflections & 6278 & 5591 \\
$\boldsymbol{R}_{\text {int }}$ & 0.09496 & 0.05146 \\
Final $\boldsymbol{R}_{\mathbf{1}}$ values (all data) & 0,0474 & 0.0372 \\
Final $\boldsymbol{R}\left(\mathbf{F}^{2}\right)$ values (all data) & 0,0481 & 0.0468 \\
Goodness-of-fit on $\mathbf{F}^{2}$ & 1.795 & 1.505 \\
\hline
\end{tabular}

therefore shows a distorted side (terpyridine coordination), and a geometrically regular side ( $\mathbf{L}$ coordination).

In contrast with complex $\mathbf{1}$, the ${ }^{1} \mathrm{H}$ NMR spectrum of complex 2 displays a sharp singlet $(5.29 \mathrm{ppm})$ in the aliphatic region. This singlet is assigned to the bridging methylene protons. This multiplicity arises from the less hindering character of the terpyridine ligand with respect to the ligand $\mathbf{L}$. In the case of complex 1 the movement is cooperative as the twisting of one ligand induces the twisting of the second one. For complex 2 the planarity of the terpyridine ligand gives more freedom to the biscarbene ligand to move. This allows fast isomerization on the NMR time scale between $P$ and $M$ helices. Recording the NMR spectra at lower temperatures provides a splitting of the signal into two doublets as the fluxionality is slowed down (Fig. 3). Decoalescence of the signal is observed around $0{ }^{\circ} \mathrm{C}$; at $-5{ }^{\circ} \mathrm{C}$ the splitting can be detected and is complete at $-45^{\circ} \mathrm{C}$. Using the Eyring equation, the rotation barrier was estimated to be 13.6 $\mathrm{kcal} \mathrm{mol}{ }^{-1}$. On the other hand, the two sets of doublets displayed in the case of complex 1 did not show any sign of merging when recording the spectrum at $70{ }^{\circ} \mathrm{C}$.

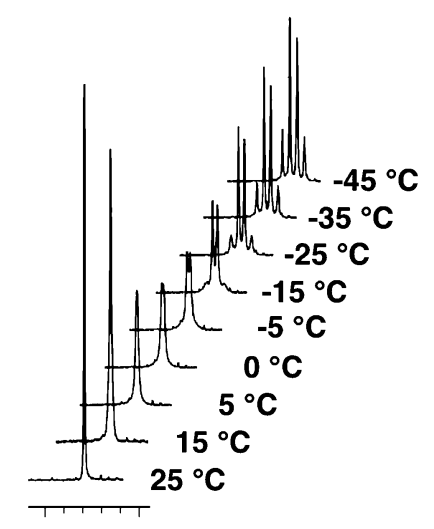

\section{$5.5 \quad 5 \quad \mathrm{ppm}$}

Fig. 3 Aliphatic region of the ${ }^{1} \mathrm{H}-\mathrm{NMR}$ spectra $\left(\mathrm{CD}_{3} \mathrm{CN}\right)$ of complex 2 recorded at different temperatures.
The redox properties of the compounds were studied by cyclic voltammetry and showed in each case a reversible monoelectronic oxidation wave at $E_{1 / 2}=0.52$ and $0.74 \mathrm{~V}\left(\Delta E_{\mathrm{p}}=72\right.$ and $\left.70 \mathrm{mV}\right)$ vs. $\mathrm{Ag} / \mathrm{AgNO}_{3} 10^{-2} \mathrm{M}$ for complex $\mathbf{1}$ and $\mathbf{2}$ respectively (Fig. 4), attributed to the oxidation of the metal centre. Compared to the $\left[\mathrm{Ru}(\text { tpy })_{2}\right]^{2+}$ complex $\left(E_{1 / 2}=0.98 \mathrm{~V}\right)$, the $\mathrm{Ru}(\mathrm{II})$ oxidation features a cathodic shift by $c a$. $0.5-0.3 \mathrm{~V}$, according to the increased electronic density on the metal ion due to the donor effect of the carbenic ligands. In the potential window investigated (ca. $+2 \mathrm{~V} /-2 \mathrm{~V}$ in acetonitrile), no reduction process could be observed in the case of compound $\mathbf{1}$ whereas complex $\mathbf{2}$ exhibited a reversible monoelectronic wave at $E_{1 / 2}=-1.67 \mathrm{~V}\left(\Delta E_{\mathrm{p}}=70 \mathrm{mV}\right)$ vs. $\mathrm{Ag} / \mathrm{AgNO}_{3}$, assigned to the reduction of the terpyridine ligand, occurring at more negative potential than for $\left[\mathrm{Ru}(\mathrm{tpy})_{2}\right]^{2+}\left(E_{1 / 2}=\right.$ $-1.36 \mathrm{~V})^{6}$ as a result of the presence of the ligand $\mathbf{L}$.

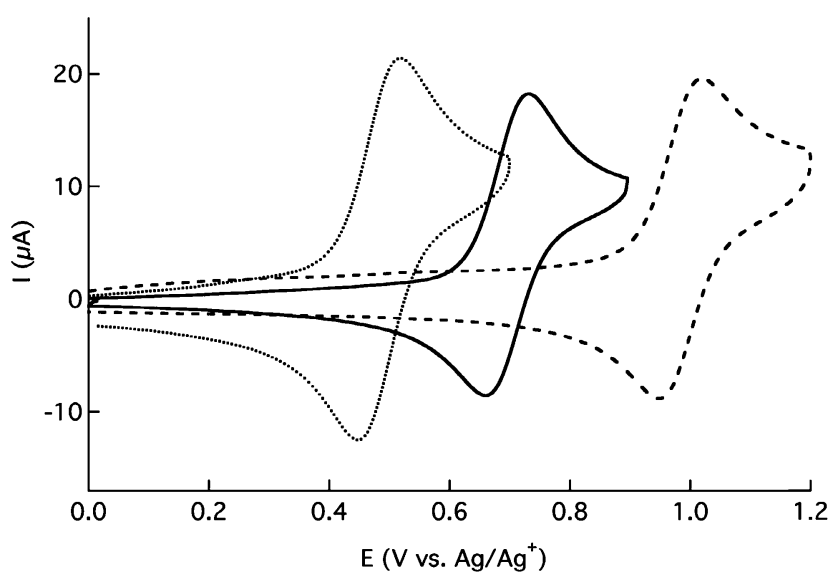

Fig. 4 Anodic region of the cyclic voltammograms of complexes 1 (dotted line), 2 (full line) and $\left[\mathrm{Ru}(\mathrm{tpy})_{2}\right]^{2+}$ (dashed line) in argon-purged acetonitrile + 0.1 M tetra- $n$-butylammonium hexafluorophosphate solution; scan rate: $100 \mathrm{mV} \mathrm{s}^{-1}$.

The absorption spectrum of complex $\mathbf{1}$ in acetonitrile exhibits a relatively intense band in the UV region $\left(\lambda_{\max }=254 \mathrm{~nm}, \varepsilon=\right.$ $32300 \mathrm{M}^{-1} \mathrm{~cm}^{-1}$ ) due to $\pi-\pi^{*}$ ligand centered (LC) transition, and a moderately intense absorption band in the visible part of the spectrum with a maximum at $429 \mathrm{~nm}\left(\varepsilon=12000 \mathrm{M}^{-1} \mathrm{~cm}^{-1}\right)$ assigned to a MLCT transition. The high energy of this transition compared to the one of $\left[\mathrm{Ru}(\mathrm{tpy})_{2}\right]^{2+6}$ is explained by the high-lying level of the $\pi^{*}$ orbitals of the ligand. Indeed, in addition to the donor effect of the carbene moiety, the presence of the methylene groups between the heterocycles forming the ligand disrupts the conjugation throughout the whole ligand. Despite its suitable geometrical features, complex $\mathbf{1}$ is non-emissive at room temperature. It has been proposed, and generally accepted, ${ }^{7,2 \mathrm{c}}$ that the quenching of the ${ }^{3}$ MLCT luminescence for $\left[\mathrm{Ru}(\text { tpy })_{2}\right]^{2+}$ involves coupling with the neighboring ${ }^{3} \mathrm{MC}$ state that is itself strongly coupled to the ground state. Various examples of ruthenium complexes have recently been reported, ${ }^{3}$ where the expansion of the metallacycles from five to six atoms greatly enhances the emission properties of bis-terdentate complexes. This behavior is assigned to a stronger ligand field that raises the strongly antibonding ${ }^{3} \mathrm{MC}$ state to higher energy levels. This is still true in the case of complex 1, however the energy level of the ${ }^{3}$ MLCT state is also high because of the donor properties of the carbenic ligand and the disrupted conjugation on the ligand therefore allowing the 
population of the non-emissive ${ }^{3} \mathrm{MC}$ state. The thermal population of the ${ }^{3} \mathrm{MC}$ state can be limited at $77 \mathrm{~K}$. In these conditions, a weak emission is detected at $530 \mathrm{~nm}(\tau=4 \mathrm{~ns})$ denoting the highly energetic character of the excited state. The unusually short lifetime observed at low temperature could be construed by the localization of the accepting orbital of the transition essentially on the pyridine ring of the ligand. The distorted nature of this excited state ( $\left.{ }^{3} \mathrm{MLCT}\right)$ induces an important coupling with the ground state and therefore accelerates non-radiative processes.

The heteroleptic complex 2 displays electronic absorption bands due to $\pi-\pi^{*}$ transitions centered on both the terpyridine and $\mathbf{L}$ ligands in the UV region at 261, 275 and $318 \mathrm{~nm}(\varepsilon=19000,18300$ and $22300 \mathrm{M}^{-1} \mathrm{~cm}^{-1}$ respectively), and a broad and less intense absorption band attributed to the ${ }^{1}$ MLCT transitions around $500 \mathrm{~nm}\left(\varepsilon=5200 \mathrm{M}^{-1} \mathrm{~cm}^{-1}\right)$ extending beyond $650 \mathrm{~nm}$ (Fig. 5), in agreement with the redox properties of the compound. The red shift of the visible absorption band compared to $\left[\mathrm{Ru}(\mathrm{tpy})_{2}\right]^{2+}$ $\left(\lambda_{\max }=474 \mathrm{~nm}\right)$ is not surprising. As the terpyridine ligand is more easily reduced than ligand $\mathbf{L}$ it is expected that the lowest energy charge transfer will take place from the metal, easier to oxidize in $\mathbf{2}$, to the terpyridine moiety. Moreover, complex $\mathbf{2}$ differentiates from both its homoleptic parent compounds as it shows room temperature luminescence. Indeed, complex $\mathbf{1}$ is non-emissive at room temperature, and $\left[\mathrm{Ru}(\mathrm{tpy})_{2}\right]^{2+}$ displays a very weak emission with a lifetime in the picosecond timescale in the same conditions. ${ }^{6}$ For complex $\mathbf{2}$, the presence of ligand $\mathbf{L}$ provides a stronger ligand field given its preferential coordination geometry. Therefore, while the ${ }^{3} \mathrm{MLCT}$ state remains low, the ${ }^{3} \mathrm{MC}$ state lies at a high energy making its thermal population less probable. This allows the complex to emit at room temperature (Fig. 5) at an energy close to the one found for $\left[\mathrm{Ru}(\mathrm{tpy})_{2}\right]^{2+}$. The room temperature emission of complex 2 in deoxygenated acetonitrile is centered at $680 \mathrm{~nm}$ with a lifetime of $5 \mathrm{~ns}$ and a quantum yield of $9 \times 10^{-4}$. This emission is attributed to deactivation from the lowest ${ }^{3}$ MLCT excited state, involving the ligand with the lowest energy $\pi^{*}$ orbitals, which is in this case terpyridine. However, its relatively short lifetime (in the nanosecond range) suggests that other competitive non-radiative processes also play a role in the deactivation of the excited state. The imidazole subunit could be assumed responsible for this effect.

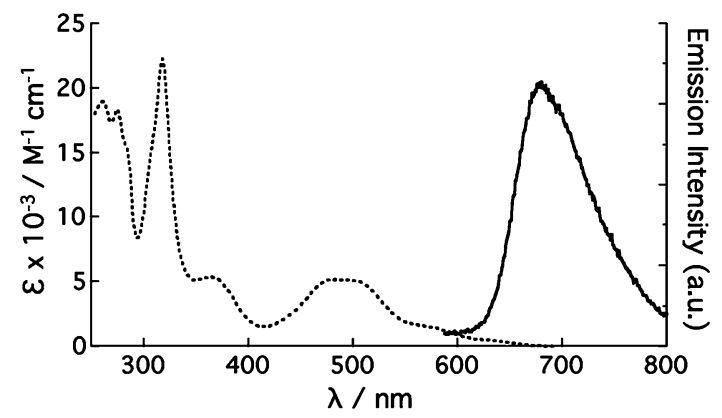

Fig. 5 Absorption (dotted line) and emission (full line) spectra of complex $\mathbf{2}$ in acetonitrile at room temperature.

At $77 \mathrm{~K}$ in butyronitrile rigid matrix, as expected this emission is blue shifted to $658 \mathrm{~nm}$, its lifetime of $6.7 \mu$ s is typical of the ${ }^{3} \mathrm{MLCT}$ Ru-tpy emitters. A schematic representation of the energy levels is depicted in Fig. 6. Another heteroleptic complex was published during the course of this study by Heinze et coll. where one of the ligands displays the six-membered metallacycle coordination mode required for optimal geometry and the second one is a terpyridine ligand. ${ }^{8}$ In addition to the favorable geometrical features, a donor (tertiary amine) and an acceptor (ester) group are attached to the extended ligand and the terpyridine respectively. The complex reaches then quite acceptable photophysical properties $\left(\Phi=3.0 \times 10^{-3} ; \tau=722 \mathrm{~ns}\right.$ at room temperature in acetonitrile) for a potential use as a photosensitizer. Heteroleptic complexes bearing a terpyridine and a bis-carbene ligand have also recently been published, but due to a strongly distorted geometry (fivemembered metallacycles) these do not feature room temperature luminescence. ${ }^{9}$

\section{Conclusion}

In conclusion, we have realized the synthesis of two new $\mathrm{Ru}(\mathrm{II})$ complexes based on a terdentate $N$-heterocyclic carbene ligand forming six-membered metallacycles. The homoleptic compound, despite a nearly perfect octahedral geometry, is not luminescent at room temperature. Heteroleptic complex $\mathbf{2}$ inherits complementary electronic properties from its ligands. On one hand, ligand $\mathbf{L}$ brings a close-to-perfect coordination geometry that helps rising the energy of the metal-centred triplet state. On the other hand, the terpyridine ligand provides low-lying $\pi^{*}$ orbitals. The combined effect of both ligands offers a greater energy gap between the ${ }^{3} \mathrm{MLCT}$ and the ${ }^{3} \mathrm{MC}$ states. The activation energy for the internal conversion is then greater and this allows the heteroleptic complex to display room temperature luminescence despite the fact that both its homoleptic analogues are virtually not luminescent at room temperature. Synthesis of further functionalized ligands is currently underway to include such compounds in higher order assemblies.

\section{Experimental}

\section{General considerations}

All purchased chemicals were used as received. ${ }^{1} \mathrm{H}-\mathrm{NMR}$ and ${ }^{13} \mathrm{C}-\mathrm{NMR}$ spectra were recorded on Brucker 300 or $400 \mathrm{MHz}$ spectrometers. ${ }^{1} \mathrm{H}$ and ${ }^{13} \mathrm{C}$ chemical shifts (ppm) were referenced to residual solvent peaks. ${ }^{10}$ Absorption spectra were recorded on a Varian Cary 300 Scan UV-Visible spectrophotometer. Emission spectra were recorded on a Varian Cary Eclipse spectrofluorimeter. Samples in acetonitrile solutions were placed in $1 \mathrm{~cm}$ path length quartz cuvettes for room temperature measurements, and in butyronitrile rigid matrix for $77 \mathrm{~K}$ measurements. Luminescence lifetimes measurements were performed after irradiation at $\lambda=$ $400 \mathrm{~nm}$ obtained by the second harmonic of a Titanium:Sapphire laser (picosecond Tsunami laser spectra physics 3950-M1BB + 39868-03 pulse picker doubler) at a $400 \mathrm{kHz}$ repetition rate. Fluotime 200 from AMS technologies was used for the decay acquisition. It consists of a GaAs microchannel plate photomultiplier tube (Hamamatsu model R3809U-50) followed by a time-correlated single photon counting system from Picoquant (PicoHarp300). The ultimate time resolution of the system is close to 30 ps. Luminescence decays were analyzed with Fluofit software available from Picoquant. Emission quantum yields $\phi$ were determined at room temperature in deoxygenated acetonitrile solutions using the optically dilute method. ${ }^{11}\left[\mathrm{Ru}(\mathrm{bpy})_{3}\right]^{2+}$ 


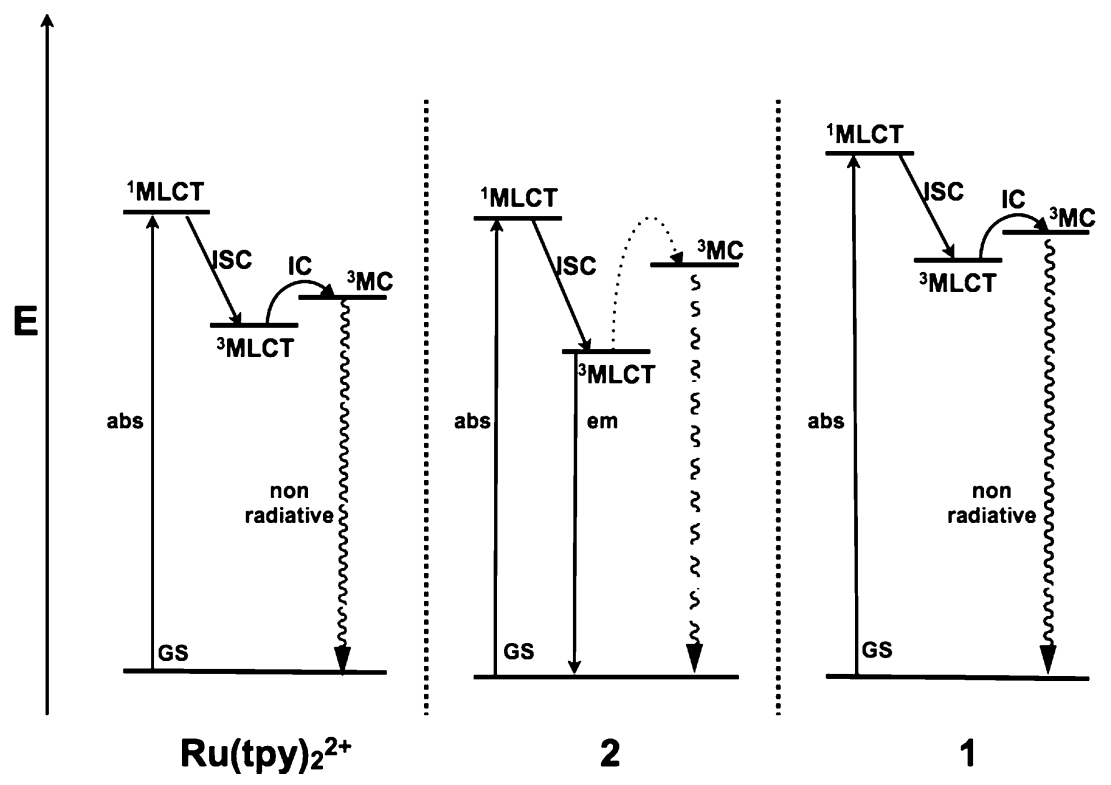

Fig. 6 Schematic Perrin-Jablonsky diagrams for $\left[\mathrm{Ru}(\mathrm{tpy})_{2}\right]^{2+}$, complexes $\mathbf{2}$ and $\mathbf{1}$ (IC: internal conversion; ISC: intersystem crossing).

(bpy $=2,2^{\prime}$-bipyridine) in air-equilibrated aqueous solution was used as quantum yield standard $(\phi=0.028) .{ }^{12}$ Electrochemical measurements were recorded using a CHI-620B potentiostat (CH Instruments). Tetra- $n$-butylammonium hexafluorophosphate $\left(\mathrm{TBAPF}_{6}\right)$ was used as supporting electrolyte $(0.1 \mathrm{M})$ in dry $\mathrm{CH}_{3} \mathrm{CN}$. A standard three-electrodes electrochemical cell was used, potentials were referenced to a $10 \mathrm{mM} \mathrm{Ag} / \mathrm{AgNO}_{3}$ reference electrode, the working electrode was a $3 \mathrm{~mm}$ diameter $\mathrm{Pt}$ disk electrode ( $E_{\mathrm{pa}}$ : anodic peak potential; $E_{\mathrm{pc}}$ : cathodic peak potential; $\left.E_{1 / 2}=\left(E_{\mathrm{pa}}+E_{\mathrm{pc}}\right) / 2 ; \Delta E_{\mathrm{p}}=E_{\mathrm{pa}}-E_{\mathrm{pc}}\right)$. Experimental uncertainties are as follows: absorption maxima, $\pm 2 \mathrm{~nm}$; molar absorption, $20 \%$; emission maxima, $\pm 5 \mathrm{~nm}$; emission lifetimes, $10 \%$; emission quantum yields, $20 \%$; redox potentials, $\pm 10 \mathrm{mV}$.

\section{Preparation of the ruthenium compounds}

$\left[\mathbf{R u L}_{2}\right]\left(\mathbf{P F}_{\mathbf{6}}\right)_{\mathbf{2}}$ (1). A suspension of anhydrous $\mathrm{RuCl}_{3}$ (121 mg, $0.58 \mathrm{mmol}), 1,1^{\prime}$-[2,6-pyridinediylbis(methylene)] bis[3methylimidazolium]dibromide $(500 \mathrm{mg}, 1.17 \mathrm{mmol})$ and sodium acetate 3-hydrate (397 mg, $2.92 \mathrm{mmol})$ in $15 \mathrm{~mL}$ ethylene glycol was stirred at $140{ }^{\circ} \mathrm{C}$ for $5 \mathrm{~h}$. After cooling to room temperature, addition of a saturated aqueous solution of $\mathrm{KPF}_{6}$ caused the precipitation of a yellowish compound. After filtration, the resulting solid was purified by column chromatography $\left(\mathrm{SiO}_{2}\right.$, $\left.\mathrm{MeCN}-\mathrm{H}_{2} \mathrm{O} / \mathrm{KNO}_{3 \text { sat }} 100 / 5 / 0.5 \mathrm{v} / \mathrm{v} / \mathrm{v}\right)$ affording $161 \mathrm{mg}(15 \%$ yield) of the desired complex as a yellow solid.

${ }^{1} \mathrm{H} \mathrm{NMR}\left(\mathrm{CD}_{3} \mathrm{CN}, 300 \mathrm{MHz}\right): \delta(\mathrm{ppm}) 7.91(\mathrm{t}, 2 \mathrm{H}, J=7.7 \mathrm{~Hz})$, $7.65(\mathrm{~d}, 4 \mathrm{H}, J=7.7 \mathrm{~Hz}), 7.41(\mathrm{~d}, 4 \mathrm{H}, J=1.9 \mathrm{~Hz}), 7.04(\mathrm{~d}, 4 \mathrm{H}, J=$ $1.9 \mathrm{~Hz}), 5.48$ (d, 4H, $J=15.4 \mathrm{~Hz}), 4.43(\mathrm{~d}, 4 \mathrm{H}, J=15.4 \mathrm{~Hz}), 2.05$ (s, 12H). ${ }^{13} \mathrm{C}$ NMR $\left(\mathrm{CD}_{3} \mathrm{CN}, 100 \mathrm{MHz}\right): \delta$ (ppm) 188.97, 159.44, 136.74, 124.96, 122.45, 121.01, 55.39, 33.30. ESI-MS: $m / z=781.03$ $\left(\left[\mathrm{M}-\mathrm{PF}_{6}\right]^{+}\right)$; calcd. for $\mathrm{C}_{30} \mathrm{H}_{34} \mathrm{~F}_{6} \mathrm{~N}_{10} \mathrm{PRu}=781.17$.

$\left[\mathbf{R u L}\left(t_{p y}\right)\right]\left(\mathbf{P F}_{6}\right)_{2} \quad$ (2). A suspension of $\left.[\mathrm{Ru}(\mathrm{tpy}) \mathrm{Cl})_{3}\right]$ (100 mg, 0,23 mmol), 1,1'-[2,6-pyridinediylbis(methylene)] bis[3-methylimidazolium]bishexafluorophosphate $(200 \mathrm{mg}$, $0.36 \mathrm{mmol})$ and sodium acetate $(670 \mathrm{mg}, 3.6 \mathrm{mmol})$ in ethylene glycol $(5 \mathrm{~mL})$ was stirred at $140{ }^{\circ} \mathrm{C}$ for $3 \mathrm{~h}$. After cooling to room temperature, addition of a saturated aqueous solution of $\mathrm{KPF}_{6}$ caused the precipitation of a red-brownish compound. After filtration, the resulting solid was purified by column chromatography $\left(\mathrm{SiO}_{2}, \mathrm{MeCN}-\mathrm{H}_{2} \mathrm{O} / \mathrm{KNO}_{3 \text { sat }} 100 / 5 / 0.5 \mathrm{v} / \mathrm{v} / \mathrm{v}\right)$ affording $54 \mathrm{mg}$ ( $26 \%$ yield) of the desired complex as a red solid.

${ }^{1} \mathrm{H}$ NMR (CD $\left.\mathrm{CN}_{3}, 400 \mathrm{MHz}\right): \delta(\mathrm{ppm}) 8.35(\mathrm{~d}, 2 \mathrm{H}, J=8.1 \mathrm{~Hz})$, $8.32(\mathrm{~d}, 2 \mathrm{H}, J=8.1 \mathrm{~Hz}), 8.20(\mathrm{~d}, 2 \mathrm{H}, J=4.7 \mathrm{~Hz}), 8.15(\mathrm{t}, 1 \mathrm{H}, J=$ $7.7 \mathrm{~Hz}), 8.08(\mathrm{t}, 1 \mathrm{H}, J=8.1 \mathrm{~Hz}), 7.98(\mathrm{ddd}, 2 \mathrm{H}, J=7.8 ; 7.8 ; 1.5 \mathrm{~Hz})$, $7.87(\mathrm{~d}, 2 \mathrm{H}, J=7,7 \mathrm{~Hz}), 7.35(\mathrm{ddd}, 2 \mathrm{H}, J=7.4 ; 5.7 ; 1.5 \mathrm{~Hz}), 7.09$ $(\mathrm{d}, 2 \mathrm{H}, J=1.9 \mathrm{~Hz}), 6.60(\mathrm{~d}, 2 \mathrm{H}, J=1.9 \mathrm{~Hz}), 5.29$ (s, 4H), 2.10 $(\mathrm{s}, 6 \mathrm{H}) .{ }^{13} \mathrm{C} \mathrm{NMR}\left(\mathrm{CD}_{3} \mathrm{CN}, 100 \mathrm{MHz}\right): \delta(\mathrm{ppm}) 178.30,159.11$, $159.08,158.42,154.53,138.79,136.88,132.99,126.68,126.46$, 123.87, 123.35, 122.5, 121.01, 54.17, 34.24. ESI-MS: $m / z=747.2$ $\left(\left[\mathrm{M}-\mathrm{PF}_{6}\right]^{+}\right)$; calcd. for $\mathrm{C}_{30} \mathrm{H}_{28} \mathrm{~F}_{6} \mathrm{~N}_{8} \mathrm{PRu}=747.1$.

\section{Acknowledgements}

The authors thank Dr Alain Deronzier for his interest in this work and the CNRS for an "ATIP Jeunes Chercheurs" funding. We are grateful to B. Gennaro (DCM, Universite Joseph Fourier, Grenoble, France) for help in temperature-dependent NMR studies and to C. Philouze (DCM) for crystal structure determination. The authors thank the reviewers for their helpful comments and considerations.

\section{References}

1 (a) A. Inagaki and M. Akita, Coord. Chem. Rev., 2010, 254(1112), 1220; (b) K. Yamaguchi, T. Okada and S. Suzuki, Inorg. Chem. Commun., 2006, 9(10), 989; (c) Y. Xu, G. Eilers, M. Borgström, J. Pan, M. Abrahamsson, A. Magnuson, R. Lomoth, J. Bergquist, T. Polivka, L. Sun, V. Sundström, S. Styring, L. Hammarström and B. Åkermark, Chem.-Eur. J., 2005, 11(24), 7305; (d) M. Borgström, N. Shaikh, O. Johansson, M. F. Anderlund, S. Styring, B. Akermark, A. Magnuson and L. Hammarström, J. Am. Chem. Soc., 2005, 127(49), 17504; (e) J.M. Zen, S.-L. Liou, A. S. Kumar and M.-S. Hsia, Angew. Chem., Int. Ed., 2003, 42(5), 577; (f) Z. Varpness, P. A. Suci, D. Ensign, M. J. Young and T. Douglas, Chem. Commun., 2009, 3726. 
2 (a) E. A. Medlycott and G. S. Hanan, Chem. Soc. Rev., 2005, 34, 133; (b) E. A. Medlycott and G. S. Hanan, Coord. Chem. Rev., 2006, 250, 1763; (c) J.-P. Sauvage, J.-P. Collin, J.-C. Chambron, S. Guillerez, C. Coudret, V. Balzani, F. Barigelletti, L. De Cola and L. Flamigni, Chem. Rev., 1994, 94, 993; (d) Y.-Q. Fang, N. J. Taylor, G. S. Hanan, F. Loiseau, R. Passalacqua, S. Campagna, H. Nierengarten and A. Van Dorsselaer, J. Am. Chem. Soc., 2002, 124, 7912; (e) E. C. Constable, C. E. Housecroft, E. R. Schofield, S. Encinas, N. Armaroli, F. Barigelletti, L. Flamigni, E. Figgemeier and J. G. Vos, Chem. Commun., 1999, 869; $(f)$ M. Duati, S. Tasca, F. C. Lynch, H. Bohlen, J. G. Vos, S. Stagni and M. D. Ward, Inorg. Chem., 2003, 42, 8377; (g) M. Beley, S. Chodorowski, J.-P. Collin, J.-P. Sauvage, L. Flamigni and F. Barigelletti, Inorg. Chem., 1994, 33, 2543.

3 (a) M. Abrahamsson, M. Jäger, T. Österman, L. Eriksson, P. Persson, H.-C. Becker, O. Johansson and L. Hammarström, J. Am. Chem. Soc., 2006, 128, 12616; (b) F. Schramm, V. Meded, H. Fliegl, K. Fink, O. Fuhr, Z. Qu, W. Klopper, S. Finn, T. E. Keyes and M. Ruben, Inorg. Chem., 2009, 48, 5677; (c) H. Wolpher, O. Johansson, M. Abrahamsson, M. Kritikos, L. Sun and B. Akermark, Inorg. Chem. Commun., 2004, $7,337$.
4 (a) S. Gründemann, M. Albrecht, J. A. Loch, J. W. Faller and R. H. Crabtree, Organometallics, 2001, 20, 5485; (b) S. D. Adhikary, T. Samanta, G. Roymahapatra, F. Loiseau, D. Jouvenot, S. Giri, P. K. Chattaraj and J. Dinda, New J. Chem., 2010, 34, 1974.

5 K. Lashgari, M. Kritikos, R. Norrestam and T. Norrby, Acta Crystallogr., Sect. C: Cryst. Struct. Commun., 1999, 55, 64.

6 C. Creutz, M. Chou, T. L. Netzel, M. Okumura and N. Sutin, J. Am. Chem. Soc., 1980, 102, 1309.

7 (a) A. Juris, V. Balzani, F. Barigelletti, S. Campagna, P. Belser and A. Von Zelewsky, Coord. Chem. Rev., 1988, 84, 85; (b) S. Pyo, E. PerezCordero, S. G. Bott and L. Echegoyen, Inorg. Chem., 1999, 38, 3337.

8 A. Breivogel, C. Förster and K. Heinze, Inorg. Chem., 2010, 49, 7052.

9 H.-J. Park, K. H. Kim, S. Y. Choi, H.-M. Kim, W. I. Lee, Y. K. Kang and Y. K. Chung, Inorg. Chem., 2010, 49, 7340.

10 H. E. Gottlieb, V. Kotlyar and A. Nudelman, J. Org. Chem., 1997, 62(21), 7512.

11 N. J. Demas and G. A. Crosby, J. Phys. Chem., 1971, 75, 991.

12 K. Nakamaru, Bull. Chem. Soc. Jpn., 1982, 55, 2697. 